\title{
Riobaldo, filósofo: uma análise do discurso do personagem de Guimarães Rosa, a partir de Josef Pieper
}

\begin{abstract}
Alexandre Medeiros ${ }^{1}$
Resumo: Grande Sertão: Veredas é um clássico da literatura brasileira. O protagonista é Riobaldo Tatarana. Este estudo questiona se seria correto atribuir ao personagem Riobaldo o "título" de filósofo. Analisa-se o discurso do personagem de Guimarães Rosa, a partir de Josef Pieper e seu conceito de filosofar.

Palavras chave: ato de filosofar. admiração. Guimarães Rosa. Grande Sertão: Veredas. Josef Pieper.

Abstract: Grande Sertao: Veredas is a classic of Brazilian literature. The main character is Riobaldo Tatarana. This paper discusses if it is possible to call him a philosopher, according to Josef Pieper's conception of philosophical act.

Keywords: philosophical act. Guimarães Rosa. Grande Sertão: Veredas. Josef Pieper.
\end{abstract}

\section{Introdução}

Muito já se escreveu sobre Grande Sertão: Veredas. Alguns intelectuais

"o compararam a Ulisses, de James Joyce. Manuel Cavalcanti Proença o analisou em paralelo com os romances de cavalaria. Evelina de Sá Hoisel rastreou seus componentes dramáticos. Leonardo Arroyo alinhavou todos seus pontos de contato com a cultura popular. Diversos já apontaram seu referencial no Fausto de Goethe" (PIZA, 1994, p. 21).

Ressalto também Daniel Piza, que apontou "os" personagens Riobaldo e Reinaldo (Diadorim), como possuindo "elementos de tragédia grega" (PIZA, 1994, p. 21). Além do próprio Guimarães Rosa, que "associou seu personagem central Riobaldo, ao Raskolnikov de Crime e Castigo, de Dostoievski” (PIZA, 1994, p. 21). Mas a novidade deste texto, como bem evidencia o título, está na busca por traçar um paralelo entre os princípios filosóficos de Josef Pieper, e o personagem Riobaldo de João Guimarães Rosa. O presente texto partirá do filósofo alemão Josef Pieper, e seu conceito de filosofar, cujo princípio está vinculado à "arte livre" de elaborar perguntas e questionamentos sobre questões óbvias, além do espanto e admiração do comum e cotidiano, provocado pelas "coisas simples". E por fim encontrará no discurso do

\footnotetext{
1. Bacharel em Administração de Empresas - UNIB. Mestrado em Ciências da Religião - UMESP. Doutorando em Ciências da Religião UMESP.

2 Optarei em todo o texto, por utilizar "personagem", nos dois gêneros, pois a "evolução linguística que, não tendo começado ontem, ainda provoca alguma confusão: o substantivo "personagem", que um dia foi exclusivamente feminino, é cada vez mais - sobretudo no Brasil - compreendido como aquilo que chamam "comum de dois", ou seja, uma palavra invariável que pode ser masculina ou feminina, conforme o caso. Barbarismo? Erro crasso? Seria preciso ser extremamente conservador para, a esta altura do século XXI, condenar algo que autores cultos vêm empregando há décadas e que todos os principais dicionários brasileiros e portugueses já aceitam: "personagem" é um substantivo de dois gêneros" (EDITORA ABRIL, 2015).
} 
personagem Riobaldo, indícios desta arkhé filosófica (LAUAND; CASTRO, 2011, p. 29). Sabendo que a extensão deste "ensaio", não nos permitirá identificar todos os atos filosóficos do personagem, destacaremos alguns, que após detida leitura da obra, identifiquei como mais relevantes para a presente discussão.

\section{Breve notícia biográfica sobre Josef Pieper e João Guimarães Rosa.}

De acordo com o Dr. Roberto Castro, filósofo da Universidade de São Paulo, o Alemão Josef Pieper, nasceu na pequena cidade de Elte em 1904. Após estudar Filosofia, Direito e Sociologia, doutorou-se na Universidade de Münster em 1928, com a tese $O$ fundamento ontológico da moral segundo Tomás de Aquino. Depois de atuar como professor assistente, em 1946 tornou-se professor de filosofia da mesma universidade. Participou como professor visitante em universidades dos Estados Unidos, Japão, Canadá e Índia. Casado, com 3 filhos, morreu em 1997 em sua casa em Münster (LAUAND; CASTRO, 2011, p. 9-10). Josef Pieper tornou-se o "grande mestre do resgate da tradição ocidental: são incomparáveis suas análises - trazendo para os dias de hoje - os antigos, especialmente Platão e Tomás de Aquino" (Apud HIROSE, LAUAND; CASTRO, 2011, p. 63).

João Guimarães Rosa nasceu em Minas Gerais em 1908. Cursou Medicina, concluindo o curso em 1930. Exerceu a Medicina no município de Itaúna, e também no $9^{\circ}$ Batalhão de Infantaria de Barbacena. Diplomata entre os anos de 1938 e 1944, culto, falava nove idiomas. Mas sua grande empreitada foi ser escritor, autor da obra prima Grandes Sertões: Veredas. Narrativa épica, com linguagem inovadora que causou impacto no meio literário. Foi eleito membro da Academia Brasileira de Letras, para a Cadeira $\mathrm{n}^{\mathbf{0}}$ 2. Três dias após a posse, o escritor sofre um infarto, falecendo no Rio de Janeiro, no dia 19 de novembro de 1967 (GUIMARÃES ROSA, 2015).

\section{Filosofia de Josef Pieper.}

Pensemos inicialmente na percepção de Josef Pieper de que a filosofia não faz parte da luta diária pela sobrevivência, ela vai e está além do cotidiano. Neste sentido ela não é "saber de funcionário", ou seja, não é uma "atividade útil", antes disso, ela é um "saber livre" (PIEPER, 2007, p. 8 e 17). Assim como a filosofia é livre, a arte também o é, portanto filosofia e poesia não são servis. Para acabar com a poesia, ou com a filosofia, basta dizerem: agora precisamos de poetas..., agora precisamos de filósofos... para tal finalidae. Pois poesia e filosofia, ambas, tem em si mesmas seu sentido e seu fim. Da mesma forma que não se pode dizer: "agora vou amar a fim de", ou ainda "agora vou amar para" (PIEPER, 2007, p. 17-19).

\section{Segundo Jean Lauand,}

A temática central do filosofar de Pieper é antropologia filosófica, onde a intuição - guiada principalmente pelos quatro grandes mestres da tradição ocidental: Platão, Aristóteles, S. Agostinho e S. Tomás - voltase para o aprofundamento do sentido do fenômeno sobretudo a partir da linguagem comum (LAUAND; CASTRO, 2011, p. 11).

É por isso que Josef Pieper, se contrapõe à René Descartes, que desejava atrelar à filosofia finalidades práticas, e também a Karl Marx, que achava que a filosofia teria que ir além de interpretar o mundo, deveria também transformá-lo. 
Pieper, diz que o caminho proposto por estes pensadores, se seguido, acabaria com a filosofia (PIEPER, 2007, p. 20-21), pois o ato filosófico é "in-útil", uma vez que o "filosofar é algo que transcende esse mundo do trabalho" (LAUAND; CASTRO, 2011, p. 27). Para Pieper, a verdadeira filosofia, ou melhor, a riqueza da filosofia, não está na satisfação das necessidades e desejos, nem no domínio da natureza, mas no simples ato de ver (PIEPER, 2007, p. 21) o que ninguém mais está vendo. Pois filosofia surge, quando o homem não se torna cego ao maravilhoso, que reside em que alguma coisa simplesmente exista. Neste sentido, a admiração é o princípio do filosofar. O filósofo e o poeta se ocupam do maravilhoso (LAUAND; CASTRO, 2011, p. 31 e 29).

\section{Josef Pieper e Riobaldo filósofo.}

Podemos destacar dois planos narrativos da obra Grande Sertão: Veredas, o diálogo de Riobaldo com compadre Quelemém, e o curso dos eventos, ou seja, o relato e a ação. De acordo com Daniel Piza, "à maneira de Sófocles", Guimarães Rosa faz do diálogo "parte da ação" (PIZA, 1994, p. 22). Riobaldo, ao contar estórias, desenrolando sua vida, seus sentimentos e seus pensamentos, apresenta-nos o personagem Reinaldo, seu amigo de infância que recebe o apelido de Diadorim, nome que segundo Augusto de Campos, "sugere divisão, dicotomia, dilema" (Apud CAMPOS, PIZA, 1994, p. 23). Para Piza, apesar da obra não ser na totalidade uma tragédia grega, os personagens centrais Riobaldo e Diadorim, carregam elementos da

forma de um drama no sentido aristotélico [...], tem um enredo simples [...] Os episódios são curtos e secundários, ainda que o livro seja longo [...] Grande Sertão: Veredas é como o universo de Riobaldo: todos os acontecimentos, ali, são pontas de um mesmo mistério (PIZA, 1994, p. 25),

Mistério este, que Josef Pieper explica, dizendo que: "o sentido interno da admiração vai na direção do mistério" (PIEPER, 2007, p. 45). Portanto começamos com Riobaldo que após refletir sobre o mal, deduz que, "tem diabo nenhum. Nem espírito. Nunca vi". Mas ao desenvolver análise sobre a maldade que já viu nas pessoas e na natureza, conclui: "Arre, ele [diabo] está misturado em tudo" (GUIMARÃES ROSA, 2012, p. 10-11). Mostra-nos claramente que ora pensa não acreditar em algo, por nunca ter visto, mas depois, ao ver e analisar o movimento da vida, volta pensar que na verdade existe e que esta misturado em tudo. E assim segue seu discurso enfatizando que,

Como é de são efeito, ajudo com meu querer acreditar. Mas nem sempre posso. O senhor saiba: eu toda a minha vida pensei por mim, forro, sou nascido diferente. Eu sou é eu mesmo. Divêrjo de todo mundo. Eu quase que nada sei. Mas desconfio de muita coisa. O senhor concedendo, eu digo: para pensar longe, sou cão mestre - o senhor solte em minha frente uma ideia ligeira, e eu rastreio essa por fundo de todos os matos, amém! (GUIMAR ÃES ROSA, 2012, p. 15).

De acordo com Josef Pieper, a causa daquilo que nos admiramos é-nos oculta, pois quem se admira é porque não sabe algo, não compreende. Quem compreende tudo não se admira. Quem não sabe, entende o fato de não saber, tem consciência de que não sabe. Seguindo Tomás de Aquino, Pieper diz que a "admiração vem pelo 
anseio de saber, da reivindicação ao conhecimento" (PIEPER, 2007, p. 45-46). Portanto para Pieper filosofia é para quem tem dúvidas, não para quem tem apenas certezas, estes não necessitam filosofar (PIEPER, 2007, p. 67). Neste sentido, a posição de humildade de Riobaldo, em admitir que não sabe todas as coisas, e que desconfia de muita coisa, ou seja, tem muitas dúvidas, mostra que nosso personagem pode ser pensado como alguém que está prestes a se tornar um filósofo, ainda mais

... que a antiga afirmação da admiração como começo da filosofia, tenha se convertido na afirmação de que no início da filosofia encontrase a dúvida (PIEPER, 2007, p. 44).

Riobaldo ao iniciar seu "ato filosófico e poético", permeia a religião, não como doutrina ou dogma, mas como experiência, sem nome, sem denominação, mas uma mistura mística de saberes que lhe conduzem ao maravilhoso. Isto nos é mostrado quando percebe que seus pensamentos, e suas dúvidas o levam a loucura, pois quanto mais pensa, mais verifica que,

...todo o mundo é louco. O senhor, eu, nós, as pessoas todas. Por isso é que se carece principalmente de religião: para se desendoidecer, desdoidar. Reza é que sara da loucura. No geral. Isso é que é a salvação - da - alma... Muita religião, seu moço! Eu cá, não perco ocasião de religião. Aproveito de todas. Bebo água de todo o rio... Uma só, para mim é pouca, talvez não me chegue. Rezo cristão, católico, embrenho a certo; e aceito as preces de compadre meu Quemelém, doutrina dele, de Cardéque. Mas, quando posso, vou no Mindubim, onde um Matias é crente, metodista: a gente se acusa de pecador, lê alto a Bíblia, e ora, cantando hinos belos deles. Tudo me quieta, me suspende. Qualquer sombrinha me refresca [...] Eu queria rezar tempo todo (GUIMARÃES ROSA, 2012, p. 16).

Podemos ver que o personagem Riobaldo, se espanta e se admira com o seu cotidiano, quase lhe causando uma confusão mental. Mas é exatamente esta tempestade de pensamento, que Josef Pieper destaca como "a admiração diante do aparentemente óbvio" (PIEPER, 2007, p. 44). Esta gera a confusão, mas este se transforma no elemento principal, pois como Pieper bem elabora,

Esse fato meramente negativo é o ponto capital. É com a confusão que a filosofia começa em absoluto, uma confusão que ela produz para si mesma $[\ldots]$ o enlouquecimento do pensamento em si mesmo [...] forma especial de loucura que consiste em alguém perder tudo menos a razão" (PIEPER, 2007, p. 44).

Portanto ao perceber sua loucura, Riobaldo está prestes a recuperar sua sanidade, mais do que isso, agora em meio a aparente confusão de pensamento, encontra sua libertação de pensamento. É livre para encontrar no cotidiano, nas religiosidades diversas, sua admiração, sua experiência livre da ilusão. De acordo com Josef Pieper, aquele que se admira está livre,

... pois as obviedades perdem sua validade até então indubitada e fica claro que elas não são definitivas. No entanto, o sentido da admiração é a experiência de que o mundo é mais profundo, mais amplo, mais 
misterioso do que parece ao entendimento comum. O sentido interno da admiração vai na direção do mistério. Ela não visa à provocação da dúvida, mas ao despertar do conhecimento de que o ser enquanto ser é incompreensível e misterioso - que o ser mesmo é mistério, no sentido genuíno: não mera inviabilidade, não absurdo, nem mesmo propriamente obscuridade. Mais que isso: mistério significa que uma realidade é incompreensível porque sua luz é inesgotável e inexaurível. É isso que experimenta propriamente aquele que se admira" (PIEPER, 2007, p. 45).

Riobaldo espantado pela incompreensão do mistério da vida e da morte, não se satisfaz, e pede para "Maria Leôncia", uma mulher profissional de rezas, que também não deixe ele fora de suas preces, e pede para esta que lhe reze "um terço, todo santo dia, e, nos domingos, um rosário", e conclui dizendo: "Viver é muito perigoso" (GUIMARÃES ROSA, 2012, p. 16). É por isso que Adélia Prado diz que "a arte está no mesmo caminho da mística e da fé religiosa", pois a beleza é uma "experiência não um discurso" (Apud, LAUAND; CASTRO, 2011, p. 34).

Continuando sua conversa, Riobaldo diz que, quem lhe ensinou a apreciar a beleza da natureza, foi seu amigo Diadorim (GUIMARÃES ROSA, 2012, p. 26). Então ele descreve um dos passeios com o amigo, não deixando de explicar que "jagunço não é muito de conversa continuada" (GUIMARÃES ROSA, 2012, p. 28).

Estávamos conversando, perto do rego - bicame de velha fazenda, onde agrião dá flor. Desse lusfús, ia escurecendo. Diadorim acendeu um foguinho, eu fui buscar sabugos. Mariposas passavam muitas, por entre as nossas caras, e besouros graúdos esbarravam. Puxava uma brisbrisa. $\mathrm{O}$ ianso de vento revinha com cheiro de alguma chuva perto. $\mathrm{O}$ chiim dos grilos ajuntava o campo, aos quadrados. Por mim, só, de tantas minúcias, não era o capaz de me alembrar. Que se hoje fosse. Diadorim, me pôs o rastro dele para sempre em todas essas quinquilhas da natureza. Sei como sei. Som como os sapos sorumbavam. Diadorim, duro, sério, tão bonito, no relume das brasas. Quase que a gente não abria a boca; mas era um delém [...] eu me esquecia de tudo, num espairecer de contentamento, deixava de pensar. (GUIMARÃES ROSA, 2012, p. 29).

Ao relatar esta estória ao lado de Diadorim, Riobaldo descreve que as pequeninas coisas que via naquele entardecer, lhe marcaram profundamente. Aquele abalo de admiração do cotidiano de um jagunço, na beira de um rio, foi tão grande que ele afirma que naquele momento se esqueceu de tudo, que parou até de pensar. Sem dúvidas, este foi um abalo poético, filosófico e religioso, causado por coisas simples, pequenas, ou como Riobaldo mesmo diz, por "quinquilhas" do cotidiano, mas que the deixaram um rastro para sempre. De acordo com Adélia Prado, fazendo alusão ao pensamento de Josef Pieper, diz que "admirar-se do que é natural é que é o bacana [...] admirar-se de um bezerro de duas cabeças, qualquer débil mental se admira, mas admirar-se do que é natural, só quem está cheio do Espírito Santo" (Apud PRADO, LAUAND; CASTRO, 2011, p. 35). Vale aqui comentário de Jean Lauand, sobre pensamento de Josef Pieper, mostrando que este abalo, não é nem ativo, nem passivo, mas acontece na desconhecida, ou melhor, esquecida voz do meio, 
Assim se compreende que [Josef Pieper] insista no filosofar (como atitude do sujeito e não na 'objetiva' filosofia): um abalo que nos sobrevém e em alguma medida, não depende do sujeito. $\mathrm{O}$ abalo filosófico - e os afins: religioso, tanático, artístico e do amor - não são ativos nem passivos: pertencem àquele âmbito (desaparecido gramaticalmente) da voz média: ações protagonizadas por mim, mas não sob meu controle [...] Não são ações ativas, que possam ser agendadas: amanhã às 16:00h vou me apaixonar; às 19:00h vou ter um abalo filosófico; às 21:00h uma inspiração poética. (LAUAND; CASTRO, 2011, p. 36).

Riobaldo ao filosofar, "transcende no inaparente do quotidiano". Como diz Jean Lauand, sem a arte, e sem a filosofia, "recaímos na quotidiana desolação" (LAUAND; CASTRO, 2011, p. 34). O interessante na filosofia de Josef Pieper, é que o ato filosófico não está alienado do cotidiano, mas antes, o ato filosófico está na simples atitude de olhar as mesmas coisas, com um olhar interpretativo diferente do sempre utilizado (PIEPER, 2007, p. 40-41). É perceber no que é cotidiano e familiar o que é verdadeiramente "estranho". Ou seja, a capacidade de se admirar com o comum, neste sentido é que o ato filosófico se assemelha ao ato poético (PIEPER, 2007, p. 42), pois a poesia se libertou do mundo, logo, "ninguém é mais livre do que o poeta" (RICOEUR, 1976, p. 71-72).

Baseada na ideia de Pieper, a filosofia nos mostra que não se faz necessário abandonar o cotidiano, o conhecido, para nos abalarmos filosoficamente ou poeticamente, não precisamos perseguir o extravagante, o estimulante, na esperança ilusória de encontrar o extraordinário (LAUAND; CASTRO, 2011, p. 33). Desta forma podemos fazer uma leitura de que este maravilhoso e extraordinário é a beleza da esperança, a alegria da promessa de um dia melhor que o outro. Riobaldo ao relatar um diálogo com um provável jovem pesquisador de minérios, diz:

Um outro doutor, doutor rapaz, que explorava as pedras turmalinas no vale do Arassuí, discorreu me dizendo que a vida da gente encarna e reencarna, por progresso próprio, mas que Deus não há. Estremeço. Como não ter Deus? Com Deus existindo, tudo dá esperança: sempre um milagre é possível, o mundo se resolve. Mas, se não tem Deus, háde a gente perdidos no vai-vem, e a vida é burra" (GUIMARÃES ROSA, 2012, p. 60).

Pois o extraordinário é o encanto e o espanto de admirar-se com as coisas simples. É por isso que Adélia Prado diz: "de vez em quando Deus me tira a poesia, aí olho para a pedra, e vejo pedra mesmo" (Apud, LAUAND; CASTRO, 2011, p. 34). Para Riobaldo "Deus existe, mesmo quando não há" (GUIMARÃES ROSA, 2012, p. 60). "Que Deus existe, sim,devagarinho, [...] Ele existe - mas quase só por intermédio da ação das pessoas [...] Coisas imensas no mundo" (GUIMARÃES ROSA, 2012, p. 343).

A consciência do não saber do personagem Riobaldo, lhe colocava em posição de admirar-se. Ao relatar outro momento de paragem de jagunços, descreve que aprendeu com Diadorim, o Reinaldo, a beleza do admirar.

Até aquela ocasião, eu nunca tinha ouvido dizer de se parar apreciando, por prazer de enfeite, a vida mera deles pássaros, em seu começar e 
descomeçar dos vôos e pousação. Aquilo era para se pegar a espingarda e caçar. Mas o Reinaldo gostava [...] ele me ensinou. Do outro lado tinha vargem e lagoas. P'ra e p'ra, os bandos de patos se cruzavam. 'Vigia como são esses...' Eu olhava e me sossegava mais. O sol dava dentro do rio, as ilhas estando claras. _É aquele lá: lindo!' Era manuelzinho-da-crôa, sempre casal, indo por cima da areia lisa, eles altas perninhas vermelhas [...] 'É preciso olhar para esses com todo carinho...'_o Reinaldo disse. Era. Mas o dito, assim, botava surpresa. E a macieza da voz, o bem-querer sem propósito, o caprichado ser - e tudo homem-d'armas, brabo bem jagunço - eu não entendia! [...] Sempre me lembro. De todos, o pássaro mais bonito gentil que existe é mesmo o manuelzinho-da-crôa (GUIMARÃES ROSA, 2012, p. 143).

Riobaldo viveu a vida inteira naquele sertão, mas as tarefas do dia a dia não lhe permitiram até aquele momento da vida, ver, ver beleza e ser abalado pela tranquilidade do comum. Situação que sempre esteve por ali, mas que até então, não havia visto. É por isso que Josef Pieper diz que filosofar significa não distanciar-se das coisas comuns do dia-a-dia, mas olhar para estas mesmas coisas com um olhar interpretativo, diferente do sempre utilizado, ou ainda, o utilizado por todos. Para Pieper filosofar, é fazer um julgamento distante das valorações corriqueiras (PIEPER, 2007, p. 40-41). A disposição do aprender a ver além do que todos viam, permitiu a Riobaldo, ser mais uma vez, abalado pela beleza. De todos os pássaros o "manuelzinho-da-crôa" seria daquele momento em diante o mais belo. Ao longo de toda a obra Riobaldo "existe para admirar". (GOETHE, in PIEPER, 2007, p. 43).

Riobaldo poderia pela dureza da vida no sertão, se tornar impermeável à admiração, pois "a pobreza daquelas terras, sina tristeza, falta d'água, brabeza do gado, triste caminhar" (GUIMARÃES ROSA, 2012, p. 466), como Josef Pieper explica, em algumas pessoas, talvez pelo dia a dia do trabalho, "o admirável não ocorre mais, não surge mais: o homem não é mais capaz de se admirar, [...] se tornou embotado, acha tudo óbvio" (PIEPER, 2007, p. 42). Mas no caso do personagem de Guimarães Rosa, ele se permitiu aprender, se permitiu espantar e se admirar, a ponto de dizer: "Eu olhava e me sossegava mais". Olhava para onde? Para o mesmo sertão. Riobaldo, então, se põe a filosofar. Pois de acordo com Josef Pieper,

... para o homem surpreendido pela face profunda do mundo, os fins imediatos da vida silenciam, pelo menos quando olha surpreendido para a face admirável do mundo [...] A prova de que a natureza humana não está disposta a nada menor que a esse fim é o fato de o homem ser capaz de experimentar o mirandum ${ }^{3}$ da criação, ser capaz de se admirar (PIEPER, 2007, 42-43).

Riobaldo no seu contínuo aprender, ao compreender a arte do filosofar, tem "um olhar interpretativo, diferente do sempre utilizado", ou ainda, o utilizado por todos. Pois como já vimos, filosofar é "fazer um julgamento distante das valorações corriqueiras" (PIEPER, 2007, p. 40). A atitude poético-filosófica de Riobaldo diante do cotidiano é espantosa, a ponto de filosofar no comum do sentimento, no normal da humanidade. Ele diz:

\footnotetext{
${ }^{3}$ De acordo com o Prof. Dr. Jean Lauand, Mirandum é a capacidade do homem de se espantar com as coisas ao seu redor. È o abalo desestruturador, que não é nem ativo, nem passivo, mas é voz média (LAUAND, 2015).
} 
Do que de uma feita, por me valer, eu entendi o casco de uma coisa. Que, quando eu estava assim, cada de-manhã, com raiva de uma pessoa, bastava eu mudar querendo pensar em outra, para passar a ter raiva dessa outra, também, igualzinho, soflagrante. E todas as pessoas, seguidas, que meu pensamento ia pegando, eu ia sentindo ódio delas, uma por uma, do mesmo jeito, ainda que fossem muito mais minhas amigas e eu em outras horas delas nunca tivesse tido quizília nem queixa. Mas o sarro do pensamento alterava as lembranças, e eu ficava achando que, o que um dia tivessem falado, seria por me ofender, e punha significado de culpa em todas as conversas e ações. O senhor me crê? $\mathrm{E}$ foi então que eu acertei com a verdade fiel: que aquela raiva estava em mim, produzida, era minha sem outro dono, como coisa solta e cega. As pessoas não tinham culpa de naquela hora eu estar passeando por pensar nelas [...] Entendi. Cumpri. Digo: reniti, fazendo finca de pé, em força para não esparramar raivas. Lembro que naquela manhã também o calor era menos, e o ar era bondoso. Aí eu à paz - com vontade de alegria [...] sozinho, em beira d'água, escutei o fife dum pássaro: sabiá ou saci. (GUIMARÃES ROSA, 2012, p. 236-237).

A estrutura do filosofar é a mesma que a da existência humana, ou seja, a estrutura intrínseca da existência humana e a do ato filosófico (LAUAND; CASTRO, 2011, p. 25). Ao transcender o mundo do trabalho, Riobaldo se permitiu ser abalado filosoficamente pelas situações que não mudam (aparentemente), diante de sentimentos de raiva e tristeza, Riobaldo reage após o abalo do mirandum, do aprendizado de si mesmo, de conhecer-se intimamente. E sua reação foi de admiração e espanto, ao acordar naquela manhã, sua vida continuou fisicamente a mesma, mas sua atitude poético-filosófica alterou o comum, naquela manhã "o calor era menos, e o ar era bondoso. Aí eu à paz - com vontade de alegria". O dia era o mesmo, o sol e o ar os mesmos, mas seu espanto foi perceber outro ambiente no mesmo. Como a admiração é a arkhé, o princípio da filosofia, aquele princípio se projetou em cada passo, e imperou no interior do processo (LAUAND; CASTRO, 2011, p. 29). Fazendo com que o mesmo local e a mesma rotina, fornecesse a Riobaldo um sabor diferente. Ele foi capaz de escutar o que não ouvia, e disse: "Aí eu à paz - com vontade de alegria [...] sozinho, em beira d'água, escutei o fife dum pássaro: sabiá ou saci" (GUIMARÃES ROSA, 2012, p. 237).

Riobaldo se coloca constantemente na posição de aprendiz, daquele que tem sede pelo saber. Seguindo Tomás de Aquino, Josef Pieper diz que a admiração é o homem silenciado, "pasmado por um instante", buscando saber o que está acontecendo, logo, "a admiração é diretamente definida mediante [...] o anseio por saber, reivindicação ativa por saber" (PIEPER, 2007, p. 46). Riobaldo atende ao princípio da filosofia que é admiração, como também permanece na atitude filosófica do constante desejo pelo saber. Neste sentido Jean Lauand complementa nossa análise dizendo que "a estrutura da educação universitária, é a mesma que a da filosofia" (LAUAND; CASTRO, 2011, p. 25). Sempre aprender, sempre se espantar, sempre se admirar. controlar:

Riobaldo ainda em um momento de sua vida é abalado sem perceber, sem

Ao que, alforriado me achei. Deixei meu corpo querer Diadorim; minha alma? Eu tinha recordação do cheiro dele. Mesmo no escuro, assim, eu tinha aquele fino de feições, que eu não podia divulgar, mas lembrava, 
referido, na fantasia da idéia. Diadorim - mesmo bravo guerreiro - ele era para tanto carinho: minha repentina vontade era beijar aquele perfume no pescoço; a lá, onde se acabava e remansava a dureza do queixo, do rosto... Beleza - o que é? [...] Ele fosse mulher, e à-alta e desprezadora que sendo, eu me encorajava: no dizer paixão e no fazer pegava, diminuía: ela no meio de meus braços! Mas, dois guerreiros, como é, como iam poder se gostar, mesmo de singela conversação por de trás de tantos brios e armas? [...] eu descuidei, e falei: _ ... Meu bem, estivesse dia claro., e eu pudesse espiar a cor de seus olhos... _; o disse, vagável num esquecimento, assim como estivesse pensando somente [...] Diadorim se pôs pra trás, só assustado. _ $O$ senhor não fala sério! [...] Arrepio como recaí em mim, furioso com meu patetear. (GUIMARÃES ROSA, 2012, p. 576-577).

Segundo Josef Pieper, poesia e filosofia são: "arte livre" (PIEPER, 2007, p. 17-19). Neste sentido exercendo a "liberdade" filosófica, o saber livre, Riobaldo se sentia "alforriado", deixando seu "corpo querer Diadorim".

Na liberdade de pensamento e sentimento, o personagem de Guimarães Rosa, foi abalado pela beleza, por uma paixão, por um desejo, e teve um encontro com o maravilhoso, uma experiência que lhe abalou. Como diz Adélia Prado, "a beleza é uma experiência, não um discurso" (Apud PRADO, LAUAND; CASTRO, 2011, p. 34).

Porque não chamar esta experiência desestruturadora, de mirandum? (PIEPER, 2007, p. 43). Este espanto que não foi nem ativo, nem passivo, uma vez que não se controla. Riobaldo pensa "eu descuidei, e falei", se arrepiou. Vale lembrar que este encontro aconteceu entre dois homens do setão, jagunços, pelo menos isto é o que ele sentia e sabia até aquele momento, para ele eram "dois guerreiros", cheios de "brabeza" e valentia. Este abalo desestruturador conduziu o jagunço Riobaldo a desejar beijar e envolver em seus braços o Reinaldo (Diadorim). Para Jean Lauand, estes abalos filosóficos e poéticos não possuem hora marcada para acontecer. É por isso que quando em um dia no caminho habitual, você se espantar com algo, que sempre esteve ali, mas que nunca antes foi visto ou sentido, dê graças, pois para Lauand tivemos uma experiência poética, filosófica e religiosa. Fomos ligados a plenitude da beleza real (LAUAND; CASTRO, 2011, p. 34-37). Partindo de Josef Pieper, "admirar-se significa ser abalado", e aquele que:

decide existir sob o signo do antigo grito de admiração [...], terá de se precaver contra a ameaça de alienação que lhe vem do mundo do trabalho. Aquele para quem tudo se torna mirandum corre o risco de se esquecer do trato manipulador cotidiano com estas realidades que lhe vêm ao encontro" (PIEPER, 2007, p. 43).

Riobaldo se esquece do "mundo do trabalho", que organiza a vida em homem e mulher, homem bravo e mulher dócil, certo e errado, bom e mal, e por um instante se desconecta e se esquece do "trato manipulador cotidiano", que determina que homem somente se apaixona por mulher. A admiração, abalou as estruturas préconcebidas que este jagunço possuía. Riobaldo se arrisca a ver o novo, e se transforma em filósofo. 


\section{Considerações finais}

Desta forma, se o princípio da filosofia é o admirar-se, o fim da filosofia é o ver concentrado, focado, sem a tensão de futuro, eis a verdadeira contemplação. Pois a theoria (contemplatio) só existe quando o homem não se tornou cego ao maravilhoso, que reside em que alguma coisa exista. Logo, tanto o filósofo como o poeta, se ocupam do maravilhoso (LAUAND; CASTRO, 2011, p. 31). Pois "filosofia não é atividade útil", uma vez que "não faz parte da luta diária pela sobrevivência", portanto ela vai além do cotidiano (PIEPER, 2007, p. 8 e 10), filosofia não é "saber de funcionário, mas é um saber de gentleman" (PIEPER, 2007, p. 17). E assim, nosso filósofo Riobaldo, permite-se ver além, theorizar, e perceber na cotidianidade que, o diabo é barulhento...:

às brutas; mas Deus é traiçoeiro! Ah, uma beleza de traiçoeiro - dá gosto! A força dele, quando quer - moço! - me dá medo pavor! Deus vem vindo: ninguém não vê. Ele faz é na lei do mansinho - assim é o milagre. E Deus ataca bonito, se divertindo, se economizando. A pois: um dia, num cortume, a faquinha minha que eu tinha caiu dentro dum tanque, só caldo de casca de curtir, barbatimão, angico, lá sei. 'Amanhã eu tiro...' - falei, comigo. Porque era noite, luz nenhuma eu não disputava. Ah, então, saiba: no outro dia, cedo, a faca, o ferro dela, estava sido roído, quase por metade, por aquela aguinha escura, toda quieta. Deixei, para mais ver. Estala, espoleta! Sabe o que foi? Pois, nessa mesma da tarde, aí: da faquinha só se achava o cabo... O cabo por não ser de frio metal, mas de chifre de galheiro. Aí está: Deus... Bem, o senhor ouviu, o que ouviu sabe, o que sabe me entende... (GUIMARÃES ROSA, 2012, p. 23).

Portanto o homem é um ser tal, que sua realização, sua suprema felicidade, se encontra na contemplação livre, orientada para a verdade, algo que tem sentido em si mesma, é o que podemos chamar de verdadeira filosofia, quando o homem se torna capaz de "ver aquilo que é", ver a "totalidade daquilo que é". Uma atitude livre, aprendiz, disposto ao lazer, sem função social. É certo que trabalhadores buscam lazer, nas férias, e ou fins de semana, mas a liberdade filosófica lhe permite desfrutar do lazer não como algo externo ao homem, mas como uma atitude, atitude da alma. $\mathrm{Ou}$ seja, o lazer para o (ser) humano filosófico, não é reposição de energia, mas mais do que isto, possui o papel de favorecer que este continue sendo homem, capaz de contemplar o mundo como totalidade (LAUAND; CASTRO, 2011, p. 45-48). Desta forma Riobaldo não se torna cego ao maravilhoso (LAUAND; CASTRO, 2011, p. 31), e consegue ver o que ninguém veria, no seu próprio dia-a-dia.

Agora, falemos um pouco de Diadorim. Filho de Joca Ramiro, grande chefe dos jagunços, que fica chocado ao verificar que seu filho tão esperado pelos seus companheiros, é na verdade uma menina. Joca Ramiro esconde-lhe o sexo, e é batizado como Reinaldo. Esta atitude meramente social condenou sua filha a viver uma mentira. Reinaldo assume o fardo como um dever filial, a Riobaldo seu amigo lhe é permitido chamá-lo de Diadorim. Mas com o passar dos tempos, a "verdade biológica vai querer aflorar". De acordo com Daniel Piza, este é "o fio condutor" (PIZA, 1994, p. 21) da obra de Guimarães Rosa, é a amizade de Riobaldo e Diadorim, que acabam se apaixonando, mas Riobaldo "se sente preso a um redemoinho diabólico" (PIZA, 1994, p.21), que o atormenta e provoca numerosos incidentes. 
É neste universo que pudemos compreender, estudando Josef Pieper e Riobaldo, que a capacidade do ser humano de se espantar com as coisas comuns, faz com que o "óbvio perca sua obviedade compacta". Em certo sentido o "chão sob os pés", deste ser humano espantado e abalado, começa a faltar. Lembremos pois, que o início da filosofia é a dúvida, a dúvida gera confusão mental, e é exatamente em meio a esta confusão que a filosofia começa. De acordo com o pensamento de Pieper, ao começar a duvidar de tudo, abandonamos todos os pressupostos. O terremoto causado pelo princípio do filosofar, nos conduz a elaborar perguntas antes não pensadas. Este estado Pieper denominou "enlouquecimento do pensamento", onde o ser humano perde tudo, menos a razão. É certo que os pressupostos serão recuperados, mas os que forem recuperados, serão aqueles gerados pelo conceito. Esta nova forma de pensar, abarcará a admiração (PIEPER, 2007, p. 43-45).

Riobaldo relata então o abalo da morte, em meio ao sofrimento e as

...lágrimas fortes que esquentavam meu rosto e salgavam minha boca, mas que já frias rolavam. Diadorim, Diadorim [...] E subiram as escadas com ele, em cima da mesa foi posto. Diadorim, Diadorim [...] Sufoquei numa estrangulação de dó [...] carecia de se lavar e vestir o corpo [...] embebendo a toalha, limpou as faces de Diadorim, casca grossa de sangue, repisado. E a beleza dele permanecia, só permanecia, mais impossivelmente [...] Os olhos dele ficados para gente ver. A cara economizada, a boca secada [...] Eu dizendo que a Mulher ia lavar o corpo dele. Ela rezava rezas da Bahia. Mandou todo mundo sair. Eu fiquei [...] Diadorim - nú de tudo [...] Diadorim era corpo de uma mulher, moça perfeita... Estarreci. A dôr não pode mais do que a surpresa. A coice d'arma, de coronha... Ela era. Tal que assim se desencantava, num encanto tão terrível; e levantei mão para me benzer - mas com ela tapei foi um soluçar, e enxuguei as lágrimas maiores. Uivei. Diadorim! [...] como eu solucei meu desespero [...] Eu estendi as mãos para tocar naquele corpo, e estremeci, retirando as mãos para trás, incendiável [...] E eu não sabia por que nome chamar; eu exclamei me doendo: -'Meu amor!' Foi assim. Eu tinha me debruçado na janela, para poder não presenciar o mundo. (GUIMARÃES ROSA, 2012, p. 598599).

De acordo com Daniel Piza, para o personagem Riobaldo, Diadorim, o Reinaldo "é homem e portanto, segundo os códigos de seu mundo não pode amá-lo". Para Piza, exatamente neste ponto a obra assume características de "tragédia aristotélica". Pois o mundo que esses personagens vivem "é um universo moral; e ambos são figuras trágicas". A Riobaldo, "como a Édipo, é proibido o conhecimento da identidade da pessoa amada, e a Diadorim, como a Electra, é proibida a revelação de sua identidade" (PIZA, 1994, p. 21).

Então no último espanto, no último mirandum que o personagem sofre na obra, o último abalo, a morte de Diadorim, gera grande dor e tristeza, mas ao mesmo tempo, produz admiração pela descoberta do mistério, que significa para Riobaldo grande libertação, pois para Josef Pieper, a admiração, atestará a "perda da ilusão", esta "desilusão" é uma verdadeira "libertação" (PIEPER, 2007, p. 43-45). Naquele momento de dor, uivando, ele diz "Meu amor!". Riobaldo está livre para declarar seu amor e sua dor, Riobaldo o filósofo do sertão. 


\section{Referências Bibliográficas}

GUIMARÃES ROSA, João, Grande Sertão: Veredas., Rio de Janeiro/RJ: Ed. Nova Fronteira, 2012

LAUAND, Jean; CASTRO, Roberto C. G., Filosofia e Educação: Universidade., São Paulo/SP: Factash Editora, 2011

LAUAND, Jean, Aulas do Colóquio em Linguagens da Religião, do programa de Pósgraduação em Ciências da Religião - Doutorado - UMESP/SBC - $1^{\circ}{ }^{\circ}$. semestre/2015

PIEPER, Josef, Que é filosofar? São Paulo/SP: Ed. Loyola, 2007

PIZA, Daniel, A Tragédia Grega e O Grande Sertão, Revista Cultura Vozes., Memória: Subversão da História., Ano 88 - Volume: 88 - Número: 4 julho/agosto/1994., São Paulo/SP: Ed. Vozes, 1994

RICOEUR, Paul, Teoria da Interpretação: o discurso e o excesso de significação., Lisboa/Portugal: Edições 70, 1976

\section{Referências digitais}

GUIMARÃES ROSA, João. Bibliografia. In: Uol http://pensador.uol.com.br/autor/ joao_guimaraes_rosa/biografia/ - acessado em 20/03/2015

EDITORA ABRIL. In: Veja http://veja.abril.com.br/blog/sobre-palavras/consultorio/ existe-o-personagem-ou-apenas-a-personagem/ - acessado em 16/04/2015. 